\title{
Basaltic rocks from Argentina used in concrete structures
}

\author{
S.A. Marfil \\ Department of Geology, INGEOSUR, Universidad Nacional del Sur, San Juan, Argentina \\ CIC of the Province of Buenos Aires, Argentina \\ F. Locati \\ CICTERRA (CONICET-UNC), Córdoba, Argentina \\ P.J. Maiza \\ Department of Geology, INGEOSUR, Universidad Nacional del Sur, San Juan, Argentina \\ L. Lescano \\ Department of Geology, Universidad Nacional del Sur, San Juan, Argentina \\ CIC of the Province of Buenos Aires, Argentina
}

\begin{abstract}
Basaltic rocks have been widely used in several countries of South America for major engineering projects, such as the hydroelectric dam "Yacyretá", built on the Paraná River, between Argentina and Paraguay. Moreover, basalts are very abundant in the Patagonia and participate in important amounts in most coarse and fine aggregates (gravel and sand). However, there are engineering works where important damage has been detected as result of the alkali-silica reaction.

The aim of this work is to study basalt quarries located in the NE of Argentina to identify deleterious species, mainly fresh and devitrified volcanic glass, expansive clays and residual cryptocrystalline silica.

Petrographical studies on thin sections and X-ray diffraction were made and the results obtained were compared with the behavior of these aggregates in structures in service and with standard test methods (accelerated mortar bar method, ASTM 1260 and dissolved silica determined according to chemical method, ASTM C289) studied in previous works.
\end{abstract}

\section{INTRODUCTION}

Basalt flows from Chacoparanaense basin cover more than $1.200 .000 \mathrm{Km}^{2}$ including Argentina, Brazil, Paraguay and Uruguay. Thickness ranges between 800 and 1000 meters reaching, in some areas, 1930 meters where more than 10 flows can be recognized (Fili et al. 1998). This material is exploited in several quarries in the provinces of Misiones, Corrientes and Entre Ríos (Argentina).

The aggregates obtained from the exploitation of basaltic layers were used in the construction of Yacyretá dam, one of the most important national hydroelectric works, located in the limit zone Argentina-Paraguay and in the inter-provincial bridge Gral. Manuel Belgrano that joins Corrientes and Resistencia cities (Argentina).
Both engineering works were constructed on the fluvial valley of the Paraná River. Also, most of the urban pavements and national and provincial roads, such as the National Road 127 are constructed with these materials. It should be noticed that this road is deteriorated as result of alkalisilica reaction development (Maiza et al. 2010).

These rocks are suitable for use as aggregates in concrete due to their physical and mechanical properties. However, there are some engineering works where important damage has been detected as result of alkali-silica reaction due to the presence of volcanic glass (fresh and devitrified) and cryptocrystalline silica (e.g. Shayan \& Quick 1988, Marfil \& Maiza 2001, Marfil et al. 2010).

In previous studies, performance of basaltic rocks (textures, mineral associations, alteration 
products, and geological ages) from different provinces of Argentina used as concrete aggregates was studied. To this end, standardized tests were used to assess the alkali-silica reactivity: accelerated mortar bar method (ASTM C 1260), mortar bar test (ASTM C 227), chemical test method (ASTM C 289) and petrographic test (ASTM C295) (Marfil et al. 1996). Although some rocks present an innocuous behavior, most of them show expansions in the mortar bars that greatly exceed the threshold values set by current regulations. Variations in the same flow were also found. This leads to study the causes of the different performances of basaltic rocks based on petrographical studies and X-Ray Diffraction (XRD) specially when flows have thicknesses such as those of the Chacoparanaense basin.

The aim of this work is to study the petrographic characteristics of basalt quarries located in the NE of Argentina to identify deleterious species, mainly fresh and devitrified volcanic glass, expansive clays and residual cryptocrystalline silica.

\section{MATERIALS AND METHODS}

\subsection{Materials}

The present work shows the results of studies conducted on materials from 3 quarries, two of which are located in Curuzú Cuatiá city (province of Corrientes) and the third one in the city of Concordia (province of Entre Ríos) in the Mesopotamia, Argentina (Fig. 1).

The study area, within Paraná and Chacoparanaense sedimentary basins, shows outcrops in Piramboia and Botucatú formations, Serra Geral basalts and their clastic intercalation of concordant

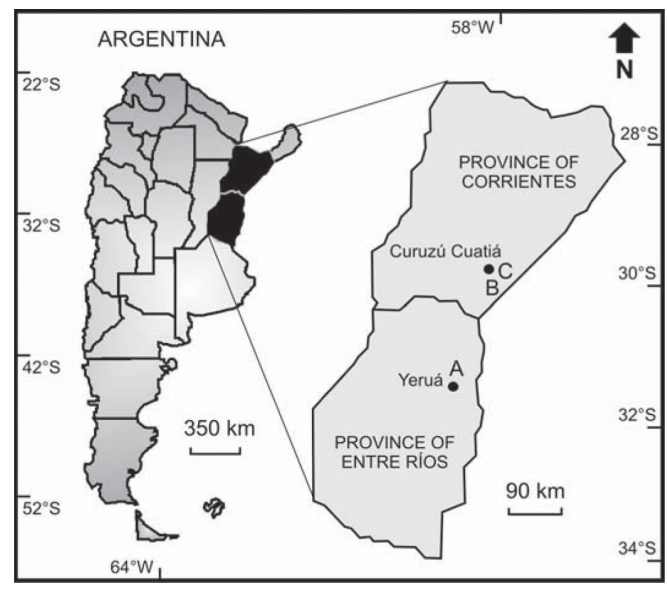

Figure 1. Location of the studied quarries. quartzitic sandstone (interbedded), indicating different stages of effusion and sedimentation (Almeida 1986, Teruggi 1970, Cortelezzi \& Gómez 1965).

The basalts are tholeitic with fine-grained texture, although they can seldom be porphyritic. Basalt rocks are dark grey to black in color (Upper Jurassic - Lower Cretacic inferior) (Turner et al. 1994, Fili et al. 1998).

Open-pit mining is carried out before the elimination of the surface layers of soil (1 to $3 \mathrm{~m}$ thick). The rock is drilled using bits and blasting to obtain blocks of 0.25 to $1 \mathrm{~m}$ in the quarry front. The rock blocks are then transported and crushed generating different sizes of aggregates to be used in concrete (Torra 1997).

Samples of active quarry fronts and gathering material were taken. Figure 2 shows one of the quarry fronts.

\subsection{Methods}

Petrographical, textural and mineralogical studies were carried out. An Olympus B2-UMA trinocular petrographic microscope with a built-in Sony 151A video camera and Image-Pro Plus image processing software were used. Mineralogical identification of clay minerals was determined by XRD, using a Rigaku D-Max III X-ray diffractometer set at $35 \mathrm{Kv}$ and $15 \mathrm{~mA}$, with $\mathrm{CuK} \alpha$ radiation (wavelength of $1.54060 \AA$ ) and a graphite monochromator in the secondary diffracted beam to remove $\mathrm{CuK} \beta$ radiation. Diffractograms from $3^{\circ}$ to $34.96^{\circ}$ $2 \theta$, in $0.04^{\circ} 2 \theta$ increments with 1 second counting time per increment were made.

To concentrate the clay minerals for their identification, a portion of the total rock was taken and ground using an agate mortar. The material $\leq 2 \mu \mathrm{m}$ was separated by decantation. The obtained fraction was centrifuged and two samples were

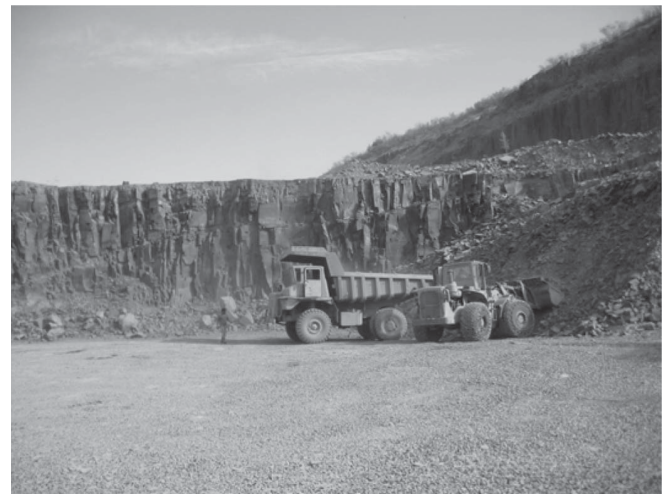

Figure 2. Curuzú Cuatiá 1 quarry front. 
prepared on glass slides. They were then placed in distilled water and dispersed with ultrasound (at $35 \mathrm{KHz} / 10 \mathrm{~min}$ ).

The natural sample was irradiated and placed with ethylene glycol for $24 \mathrm{~h}$. It was then reirradiated for expansibility determination. The second sample was calcined at $500{ }^{\circ} \mathrm{C}$ for $2 \mathrm{~h}$.

\section{RESULTS}

\subsection{Yeruá}

The rock is a tholeitic basalt with intersertal texture although in part may be intergranular. It is composed of andesine phenocrystals with irregular borders where pyroxens (augite and titaniferous augite) and opaque minerals are found. The volcanic glass $(\mathrm{V})$ is altered to clay minerals (Cly) as observed in Figure 3. Reddish coloration of the rock is due to iron leaching.

\subsection{Curuzú Cuatiá 1}

The rock with irregular edges is composed of plagioclase phenocrysts, augite and titaniferous augite. The two pyroxens showed differential alteration, mainly desferrization and chloritization. These processes produce abundant opaque minerals, mainly iron oxides (hematite). In the intercrystalline spaces, clay minerals from palagonite devitrification are identified. Apatite and iron and titanium minerals are abundant. Twinned andesine crystals as large as $1 \mathrm{~mm}$ with titaniferous augite, contained in the crystalline interspaces are observed. These minerals are developed in a mass of plagioclase phenocrystals of similar composition, opaque minerals and augite grains with

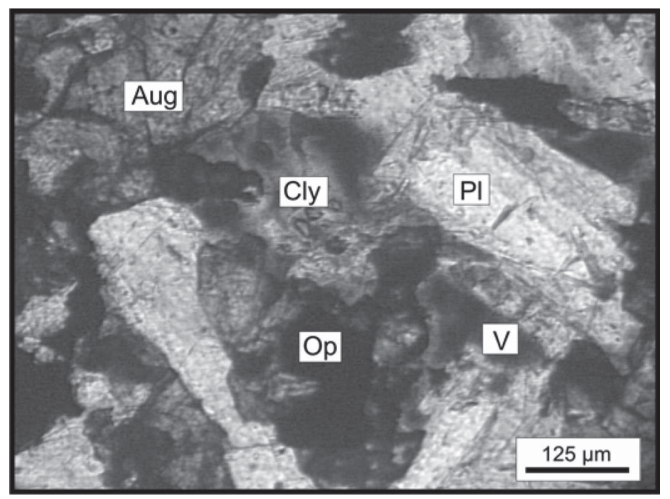

Figure 3. Clay minerals (Cly) generated by devitrification of palagonite $(\mathrm{V})$ and contained between plagioclase phenocrysts ( $\mathrm{Pl}$ ), opaque minerals (Op) and augite (Aug). (With parallel light). clay minerals. The texture is pilotaxitic to intersertal though xenolites with granular texture composed of plagioclase and large crystals of monoclynic pyroxenes are frequently found.

The alteration process causes the precipitation of clays (nontronite) and cryptocrystalline silica. The rock has undergone feldspatization, detected by the presence of intergrown anhedral sanidine.

Nontronite, ferriferous saponite, chlorite and celadonite associated with cryptocrystalline silica (trydimite) were identified by XRD.

Figure 4 shows the rock texture and the presence of abundant clay minerals.

Figure 5 compares the diffraction patterns of the natural, glicolated and calcined $\left(500{ }^{\circ} \mathrm{C}\right)$

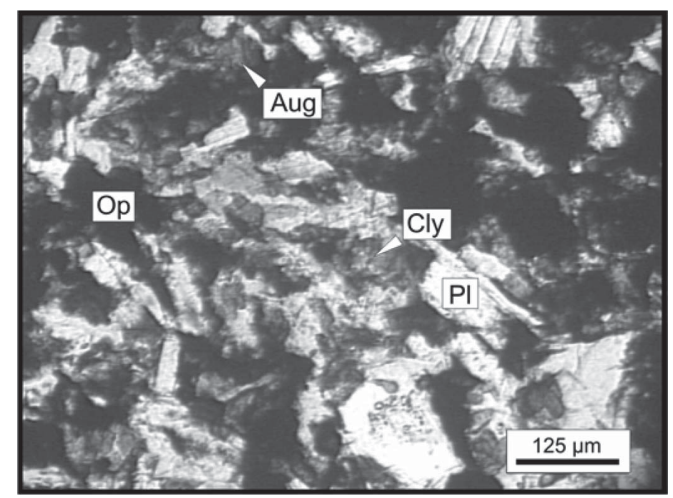

Figure 4. Texture of the rock from Curuzú Cuatiá 1 quarry with parallel light. (Aug: augite; Op: opaque minerals; Cly: clay minerals; Pl: plagioclase).

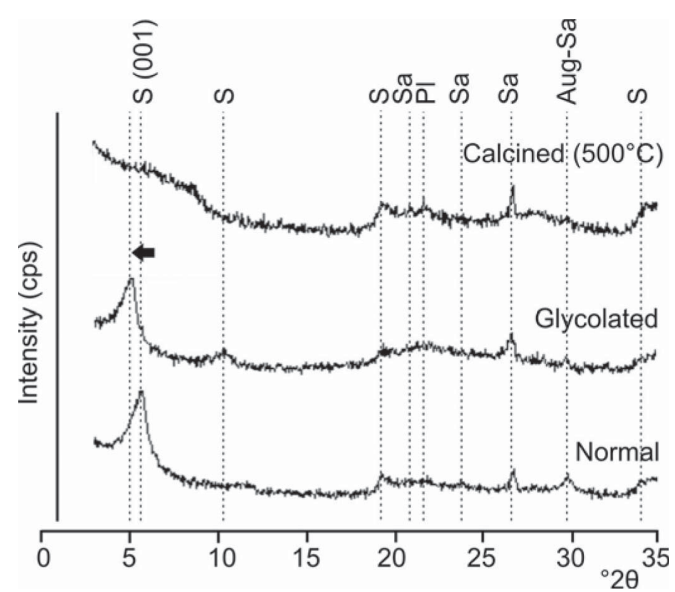

Figure 5. Diffractograms of the natural, glicolated and calcined (at $500{ }^{\circ} \mathrm{C}$ ) samples. The black arrow indicates the shift of 001 reflection of the expansive clay. S: Smectite, Sa: Sanidine, Aug: Augite, Pl: Plagioclase. 
samples from Curuzú Cuatiá 1 quarry. The 001 reflection of clay ( $15 \AA)$ in the natural sample, is shifted at $\sim 17 \AA$ with ethylene glycol and it disappears when is calcined. This allows to confirm that it is an expansive clay belonging to the smectite group (with major coincidence with saponite).

\subsection{Curuzú Cuatiá 2}

The rock is composed of plagioclase phenocrystals (andesine) of irregular prismatic shape as a result of augite and titanipherous augite crystallization. The texture is intersertal. Iron and titanium oxides are abundant. Feldspar is weakly altered, mainly argillized.

The secondary minerals are commonly located in fractures and twin and cleavaje planes of feldspars. Augite is chloritized and in some sectors closely associated with opaque minerals formed as result of augite alteration.

Intergranular zones occupied by glassy material are frequently observed (Fig. 6). This process produces abundant clay minerals. Montmorillonite, chlorite and a small amount of celadonite were determined by XRD. In other sectors isotrope material, (considered relictic from the original palagonite) was observed. Apatite is abundant.

\subsection{Discussion}

Earlier studies assessed the potential reactivity of these rocks with reference to the alkali-silica reaction using standardized methods such as ASTM C1260 and ASTM C289 (Marfil et al. 2010).

The results in Table 1 show that expansion at 16 days greatly exceeds the threshold values set by the standards $(0.20 \%)$, therefore, the materials should be classified as potentially reactive.

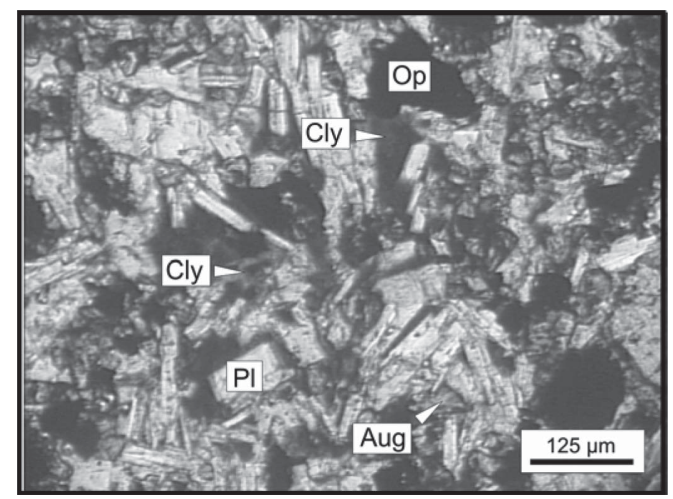

Figure 6. Texture of the rock from Curuzú Cuatiá 2, with parallel light. (Aug: augite; Op: opaque minerals; Cly: clay minerals; Pl: plagioclase).
Table 1. Expansion in mortar bars (accelerated method) and dissolved silica (Marfil et al. 2010).

\begin{tabular}{lll}
\hline Quarry & $\begin{array}{l}\text { Dissolved silica } \\
(\mathrm{mg} / 100 \mathrm{~mL})\end{array}$ & $\begin{array}{l}\text { Expansion at } \\
16 \text { days }(\%)\end{array}$ \\
\hline Yeruá & 49.3 & 0.503 \\
Curuzú Cuatiá 1 & 43.9 & 0.452 \\
Curuzú Cuatiá 2 & 49.2 & 0.425 \\
\hline
\end{tabular}

Table 2. Percentage of glass and clay in samples of crushed basalt.

\begin{tabular}{lll}
\hline Sample & $\begin{array}{l}\text { Volcanic glass } \\
(\%)\end{array}$ & $\begin{array}{l}\text { Clay mineral } \\
(\%)\end{array}$ \\
\hline 1 & 1.5 & 2.0 \\
2 & 0.2 & 4.0 \\
3 & 2.4 & 2.8 \\
4 & 2.5 & 2.2 \\
\hline
\end{tabular}

Dissolved silica content is also high, being able to react with the alkalis in the concrete and to develop deleterious reactions.

Considering the petrographic characteristics of the studied rocks, the main source of soluble silica is volcanic glass and cryptocrystalline silica (tridymite) caused by glass alteration. The presence of expansive clays can contribute to increase the expansion values in the accelerated mortar bar test method.

The relationship between expansion and the content of clays and volcanic glass was studied in a previous work (Rocco et al. 2012). To this end, samples of crushed basalt impregnated in epoxy resins were used to obtain a representative sample of the aggregate processed at the quarry.

The study was made on thin sections. The particles observed in the field of the microscope were counted and the percentage of glass and clay was determined. The procedure was repeated 5 times (in 5 fields) using magnification $\times 50$ and 5 more times with $\times 100$ magnification. Determinations were averaged out on the 10 fields. Table 2 shows the obtained results.

Volcanic glass content and clay minerals greatly correlate with dissolved silica and with the expansion measured in the mortar bars.

The correlation increases when volcanic glass $(\%)+$ clay minerals are plotted, therefore clay minerals are considered to contribute to the expansion.

Although all the studied rocks are classified as potentially reactive with respect to the ASR, they are the only available aggregates in a wide region of Argentina and the use of higher-quality 
aggregates is not economically workable due to the freight cost.

Most of the concrete used in pavements, roads, runways, bridges and important engineering constructions like Yacyretá dam, is made with these materials.

In previous works, deteriorated concretes elaborated with basaltic aggregates were studied (Maiza et al. 2010). They constitute a section of National Road 127, pavements in Curuzú Cuatiá city (near the quarries) and a runway in Corrientes city. In all the concretes the aggregates used were those studied in the present work, which concluded that the major cause of deterioration was the development of ASR. The concretes showed severe cracking with development of neoformation materials (zeolites, ettringite and amorphous and/or cryptocrystalline silica).

Considering the above mentioned data and that Yacyretá dam presents some sectors with incipient reaction processes, monitoring should be implemented on site work to determine the damaged areas and to propose mitigation strategies.

However, not all concretes made with these materials have developed ASR. Some of them are in excellent conditions.

Three conditions are essential to ASR development: alkalis, reactive silica and sufficient moisture. If one of these conditions is not present, the reaction will not occur. Therefore, it is very important to evaluate the reactivity of these rocks before using them as aggregates, by taking preventive measures such as the use of puzzolanic materials.

\section{CONCLUSIONS}

- The petrographical study shows that all studied rocks are tholeitic basalts, with intersertal texture that contain abundant volcanic glass (palagonite) altered to clay minerals (montmorillonite, celadonite, saponite and nontronite). Fresh relictic glass was also observed.

- The presence of cryptocrystalline silica (tridymite) was identified as consequence of the alteration processes (devitrification).

- The results obtained indicate that basalts from the Curuzú Cuatiá and Yeruá quarries are potentially reactive with respect to the alkali-silica reaction due to the presence of volcanic glass (fresh and altered) and cryptocrystalline silica.

- The presence of expansive clays may contribute with the concrete expansion.

- These results correlate with the dissolved silica and the expansion in the mortar bars determined in previous works using standardized test methods.

- These rocks are widely found in the region and they are, in most cases, the only available aggregates, so is necessary to take preventive measures to avoid the alkali-silica reaction development, such as the use of pozzolanic materials.

\section{ACKNOWLEDGEMENTS}

The authors wish to thank the ANCyPT, CICTERRA (CONICET-UNC), CIC of the Province of Buenos Aires, and Geology Department of the Universidad Nacional del Sur for their support during the research.

\section{REFERENCES}

Almeida, F. 1986. Distribuição regional e relações tectônicas do magmatismo pós-Paleozóico no Brasil Revista Brasileira de Geociências. 16(4): 325-349.

ASTM C227. 2010. Standard Test Method for Potential Alkali Reactivity of Cement-Aggregate Combinations. (Mortar-Bar Method). Annual Book of ASTM Standards (04.02): $6 \mathrm{pp}$.

ASTM C289. 2007. Standard Test Method for Potential Alkali-Silica Reactivity of Aggregates (Chemical Method). Annual Book of ASTM Standards (04.02): $7 \mathrm{pp}$.

ASTM C295. 2008. Standard Guide for Petrographic Examination of Aggregates for Concrete. Annual Book of ASTM Standards (04.02): 9 pp.

ASTM C1260. 2007. Standard Test Method for Potential Alkali Reactivity of Aggregates (Mortar-Bar Method). Annual Book of ASTM Standards (04.02): 5 pp.

Cortelezzi, C. \& Gómez, V. 1965. Los basaltos tholeíticos de la perforación Nogoyá (Provincia de Entre Ríos). Acta Geológica Lilloana. VI: 87-98. San Miguel de Tucumán.

Fili, M.; Da Rosa Filho, E.; Auge, M.; Montaño Xavier, J. \& Tujchneider, O. 1998. El acuífero Guaraní. Un recurso compartido por Argentina, Brasil, Paraguay y Uruguay (América del Sur). Instituto Tecnológico Geominero de España. Boletín Geológico y Minero. 109(4): 389-394.

Maiza P.; Marfil, S.; Rocco, C.; Fava, C. \& Tobes, J. 2010. Pavimentos de hormigón elaborados con agregados basálticos y afectados por Reacción álcali Sílice (RAS). Casos de estudio. "I Congreso Hormigón Premezclado de las Américas 2010", "XII Congreso Iberoamericano del Hormigón Premezclado", "IV Congreso Internacional de Tecnología del Hormigón" y "18 Reunión Técnica de la Asociación Argentina de Tecnología del Hormigón". Mar del Plata. 12 pp.

Marfil, S.; Batic, O.; Maiza, P.; Grecco, L. \& Falcone, D. 2010. Comportamiento de Rocas Basálticas de las Prov. de Corrientes y Entre Ríos Frente a la Reacción Álcali-Sílice. Proc. VI Congreso Uruguayo de Geología. Parque UTE Lavalleja, Uruguay 6 pp.

Marfil, S. \& Maiza, P. 2001. Basaltic rocks: their use as concrete aggregates. Aggregate 2001-Environment and Economy. Ed. P. Väisanen \& R. Uusinoka. Finland. Vol 1: 203-206. 
Marfil, S.; Maiza, P.; Bengochea, A.; Sota, J. \& Batic, O. 1998. Relationships between $\mathrm{SiO}_{2}, \mathrm{Al}_{2} \mathrm{O}_{3}, \mathrm{Fe}_{2} \mathrm{O}_{3}, \mathrm{CaO}$, $\mathrm{K}_{2} \mathrm{O}$ and expansion in the determination of the alkali reactivity of basaltic rocks. Cement and Concrete Research. Ed. Elsevier. USA 28 (2): 189-196.

Rocco, C.; Maiza, P.; Fava, C.; Marfil, S. \& Tobes, J. 2012. Estudio de reactividad alcalina potencial de basaltos procedentes de yacimientos ubicados en la Mesopotamia Argentina. $V$ Congreso Internacional de la AATH y $19^{\circ}$ Reunión Técnica. Actas. Bahía Blanca: 159-166.

Shayan, A. \& Quick, G. 1988. An alkali-reactive basalt from Queensland, Australia. International Journal of Cement Composites and lightweight Concrete. 10(4): 209-214.
Teruggi, M. 1970. Bosquejo Geológico del Paraguay y la Provincia de Corrientes. Boletín de la Sociedad Argentina de Botánica. XI: 1-17. Buenos Aires.

Torra, R. 1997. El universo geodinámico de la provincia de Misiones. Informe Final del Proyecto de Investigación PI-331 (SGCyT-UNNE). Centro de Geociencias Aplicadas. 4: 36-52.

Turner, S.; Regelous, M.; Kelly, S.; Hawkesworth, C. \& Mantovani, M. 1994. Magmatism and continental break-up in South Atlantic: High precision Ar-40Ar-39 geochronology. Earth and Planetary Science Letters. 121: 333-348. 